Jurnal

\title{
Guideline Compliance in the Management of Patients with Unstable Angina/Non-STEMI without PCI Procedure (Medically Managed Registry)
}

\author{
Erwinanto 1, Angke Widya², Nahar Taufik ${ }^{3}$, Sri Diniharini ${ }^{4}$, Dolly Kaunang ${ }^{5}$, \\ Arini Setiawati6,7
}

'Division of Cardiology \& Vascular Medicine, Department of Internal Medicine, Hasan Sadikin Hospital, Bandung

2Borromeus Hospital, Bandung ${ }^{3}$ Division of Cardiology \& Vascular Medicine, Department of Internal Medicine, Sardjito Hospital, Yogyakarta

${ }^{4}$ Puri Cinere Hospital, Depok ${ }^{5}$ Husada Hospital, Jakarta ${ }^{6}$ Clinical Study Unit, Faculty of Medicine, University of Indonesia, Jakarta

${ }^{7}$ Department of Pharmacology and Therapeutics - Faculty of Medicine, University of Indonesia, Jakarta
Aim: To document current usage of antiplatelet therapy and the implementation of ACC/AHA 2007 guideline in the clinical management of unstable angina/ non-ST-elevation myocardial infarction (UA/NSTEMI) patients not undergoing $\mathrm{PCl}$ procedure in Indonesia (medically managed) and their risks according to Global Registry of Acute Coronary Events (GRACE) score as well as in-hospital mortality.

Method: A multicenter observational, prospective disease registry, recruiting patients with UA/NSTEMI. No specific treatment will be recommended in this disease registry. Data will be collected based on Physician's applicable daily practices without any intervention.

Results: A total of 467 eligible patients, 246 patients with UA and 22I with NSTEMI, aged 18 years or older were recruited from 18 hospitals during December 2009 - January 20I I. Most recruited patients were at low risk $(63.9 \%)$ and only $0.9 \%$ patients were at high risk according to the GRACE score. Patients were treated with ASA (90.6\%) and Clopidogrel $(96.6 \%)$ when they reached the emergency department. Medical therapy instituted during hospitalization were injectable anticoagulant (9l.4\%), oral anticoagulant $(0.9 \%)$, oral nitrate $(82.7 \%)$, beta blocker $(60.8 \%)$, ACE inhibitor (49\%), angiotensin receptor blocker (20.3\%), calcium channel blocker (19.9\%), statin (13.1\%), and other medications given according the presentation of complications or comorbidities. In-hospital mortality was documented in $3.2 \%$ of patients. At discharge ASA was given to $87.6 \%$ and clopidogrel to $94.2 \%$ patients.

Conclusion: The result showed that most of the patients admitted with UA/NSTEMI were at low or moderate risk according to GRACE score. Although treatment with antiplatelet and anticoagulant largely followed the ACC/AHA guidelines, however, this registry documented under treatment of other medications such as ACE-inhibitors and beta blockers. Reinforcement of the guideline compliance and continuous medical education would provide better outcomes for the patients.

(J Kardiol Indones. 20 I4;35:263-7I)

Keywords : UA / NSTEMI, Registry, Medically Managed 
Jurnal

Kardiologi Indonesia

J Kardiol Indones. 20|4;35:263-7|

ISSN $0126 / 3773$

\title{
Pedoman Kepatuhan dalam Pengelolaan Pasien dengan stabil Angina/Non-STEMI tanpa PCI Prosedur (Registry Medis Dikelola)
}

\author{
Erwinanto ', Angke Widya ${ }^{2}$, Nahar Taufik ${ }^{3}$, Sri Diniharini ${ }^{4}$, Dolly Kaunang 5 , \\ Arini Setiawati ${ }^{6,7}$
}

\begin{abstract}
Tujuan: Registri ini utamanya bertujuan melakukan dokumentasi terhadap pasien yang mendapatkan terapi antiplatelet dan implementasi pedoman tatalaksana klinis dari ACC/AHA bagi pasien angina tidak stabil/infark miokard tanpa elevasi segmen ST yang tidak menjalani terapi reperfusi di Indonesia (Medically Managed Registry). Tujuan tambahan adalah mengetahui tingkat risiko pasien berdasarkan Global Registry of Acute Coronary Events (GRACE) dan tingkat kematian selama perawatan di rumah sakit.

Metodologi: Registri prospektif dan multi-senter dengan cakupan pasien yang telah terdiagnosis angina tidak stabil/infark miokard tanpa elevasi segmen ST yang tidak menjalani terapi reperfusi. Registri ini tidak merekomendasikan intervensi apapun. Data dicatat sesuai praktik dokter yang merawat.

Hasil: Dari 18 rumah sakit di Indonesia, selama periode Desember 2009 sampai dengan Januari 2011, tercatat 467 pasien yang mempunyai kesesuaian dengan inklusi dan eksklusi, terdiri dari 246 pasien dengan angina tidak stabil dan 221 pasien dengan infark miokard tanpa elevasi segmen ST. Sebagian besar $(63,9 \%)$ pasien mempunyai risiko rendah dan hanya $0,9 \%$ berisiko tinggi sesuai kriteria GRACE. Sebanyak 90,6\% pasien mendapat terapi ASA dan 96,6\% mendapat terapi clopidogrel saat dirawat di ruang gawat darurat. Terapi medikal yang diberikan selama perawatan rumah sakit adalah sebagai berikut: antikoagulan intravena $(91,4 \%)$, antikoagulan oral $(0,9 \%)$, preparat nitrat oral $(82,7 \%)$, penyekat beta $(60,8 \%)$, inhibitor ACE (49\%), penyekat reseptor angiotensin (20,3\%), calcium channel blocker $(19,9 \%)$, statin (13,1\%), dan obat lain sesuai komplikasi dan penyakit penyerta. Dari seluruh pasien, tercatat 3,2\% meninggal selama perawatan rumah sakit. Terdapat $6,3 \%$ dari pasien dengan diagnosis infark miokard dan $0,4 \%$ dari pasien dengan diagnosis angina tidak stabil meninggal selama perawatan rumah sakit. Terapi antiplatelet yang diberikan saat meninggalkan rumah sakit adalah ASA (87,6\%) dan clopidogrel (94,2\%).

Kesimpulan: Sebagian besar pasien mempunyai risiko rendah dan menengah berdasarkan kriteria GRACE. Sebagian besar pasien mendapatkan terapi antiplatelet yang dianjurkan oleh pedoman ACC/AHA. Registri ini mencatat sedikit pasien mendapatkan pengobatan seperti penyekat beta dan inhibitor ACE. Diperlukan usaha meningkatkan ketaatan menggunakan terapi medikal yang dianjurkan oleh pedoman tatalaksana pengobatan melalui pendidikan berkelanjutan.
\end{abstract}

(J Kardiol Indones. 2014;35:263-71)

Kata kunci: Angina tidak stabil / infark miokard non-elevasi segmen ST, Registri, Medically Managed

\begin{abstract}
Alamat Korespondensi
Dr. Erwinanto, I Division of Cardiology \& Vascular Medicine, Department of Internal Medicine, Hasan Sadikin Hospital, Bandung.

E-mail : ewnkar@yahoo.com
\end{abstract}


$\mathrm{T}$ The GRACE risk score is a simple, robust tool for predicting in-hospital mortality in patients with acute coronary syndrome (ACS) and can be useful to assist in decision making with regard to treatment options in patients with ACS. ${ }^{1}$ Invasive strategy is preferred for patients with high risk score and conservative strategy is preferred for those with low risk score.

The ACC/AHA (American College of Cardiology/American Heart Association) 2007 guideline recommendations reflect a consensus of expert opinion following a thorough review of late-breaking clinical trials deemed to have an impact on patient care. The guidelines attempt to define practices that meet the needs of most patients in most circumstances. The writing group of several guidelines continues to emphasize the importance of giving consideration for the use of cardiovascular medications that have been proven in randomized clinical trials to be of benefit.

Some medications such as ASA, clopidogrel, injectable anticoagulant, beta blocker, ACE inhibitor or angiotensin receptor blocker, and statin when given to patients with UA/NSTEMI have been associated with improvement in cardiovascular morbidity and mortality and therefore included into class I medications.

Despite the growing number of hospitals with ability to perform percutaneous coronary intervention $(\mathrm{PCI})$ in Indonesia, the total numbers of such hospitals are still limited. Most patients with UA/NSTEMI are predicted to be still treated medically irrespective of their GRACE risk score. Current data in Indonesia about guidelines compliance of patients treated medically are usually derived from single center or hospital.

The primary objective of this study is to document current usage of antiplatelet therapy and the implementation of ACC/AHA guideline in the clinical management of UA/NSTEMI patients without PCI procedure in Indonesia (Medically Managed Registry). The secondary objectives are to explore the UA/ NSTEMI patients in Indonesia from their demographic data, risk level according to GRACE score, and to detect in-hospital mortality.

\section{Methods}

\section{Study design}

This was a multicentre, observational, prospective disease registry. The primary objectives of this study are to assess current usage of antiplatelet therapy and ACC/AHA2007 guideline in the clinical management of unstable angina/ non-ST-elevation myocardial infarction (UA/NSTEMI) patients not undergoing PCI procedure in Indonesia. Secondary objectives are to describe the demographic data of UA/NSTEMI patients in Indonesia and to assess risks of patients according to GRACE score.

To document current usage of antiplatelet therapy and the implementation of ACC/AHA 2007 guideline in the clinical management of unstable angina/ nonST-elevation myocardial infarction (UA/NSTEMI) patients not undergoing PCI procedure in Indonesia (medically managed) and their risks according to Global Registry of Acute Coronary Events (GRACE) score as well as in-hospital mortality.

\section{Study patients}

Study participants were recruited consecutively from 18 centers (10 centers have coronary intervention facility) in Indonesia. Patients with UA/NSTEMI (positive chest pain and ST segment depression and/or $\mathrm{T}$ wave inversion with or without elevated of troponin or $\mathrm{CKMB}$ ), not planned for invasive procedure at the time of diagnosis, aged 18 years or older, and were willing to sign informed consent form were eligible to be included in this study. Pregnant or breast-feeding women and patients who participated in other clinical study were excluded from the study. The study was started in December 2009 and ended in January 2011.

\section{Study procedure}

Patients were treated according to the physician daily practices without any intervention from the investigator. Data were recorded in the DCF (Data Collection Form) for each patient during hospitalization. Data were gathered on: demographic, risk factors, medical management, duration of hospital stay, in-hospital mortality, and left ventricular systolic function.

\section{Statistical analysis}

Descriptive statistics were used. Continuous variables were summarized as mean, standard deviation, median and range. Nominal variables were summarized as frequencies and percentages. The analysis is planned to describe at baseline subject characteristics, including 
risk factors, atherothrombotic disease and anti platelet therapies. No comparison analysis will be made

The study was conducted after approval by local ethic committee.

\section{Results}

A total of 467 UA/NSTEMI patients not selected for invasive procedure at the time of diagnosis, consist of $246(52.7 \%)$ with unstable angina and 221(47.3\%) with NSTEMI, were recruited from 18 participating centers from December 2009 to January 2011.

Baseline characteristics were shown in Table 1. Mean age was 58.6 years and more than $60 \%$ of the patients were males. Among $47 \%$ of patients who have their left ventricular ejection fraction (LVEF) measured during hospitalization, 20.6\% have LVEF less than $40 \%$. Hypertension was the most frequent documented risk factor. About $60 \%$ of patients reached the emergency department before 12 hours from the onset of ACS (see Table 2).

During hospitalization, diagnostic angiography procedures were performed in 89 patients (19.1\%) at $3-4$ days after admission and 57 of them (12.2\%) underwent PCI. Average duration of the hospital stay was 6 to 7 days, which was 2-3 days longer in those who underwent PCI during hospitalization.

There were 15 patients (3.2\%) who died during hospitalization. These consisted of 12 patients $(2.9 \%)$ in the medical treatment group and 3 patients $(5.3 \%)$ among those who underwent PCI, leaving 452 patients alive at the end of the study. In-hospital mortality of patients admitted with unstable angina was $0.4 \%$ compared with $6.3 \%$ of those with NSTEMI.

Data of antiplatelet treatment during hospitalization was not available in 4 patients. Table 4 shows that dual antiplatelet therapy, aspirin and clopidogrel,

Table 1. Patients' baseline characteristics

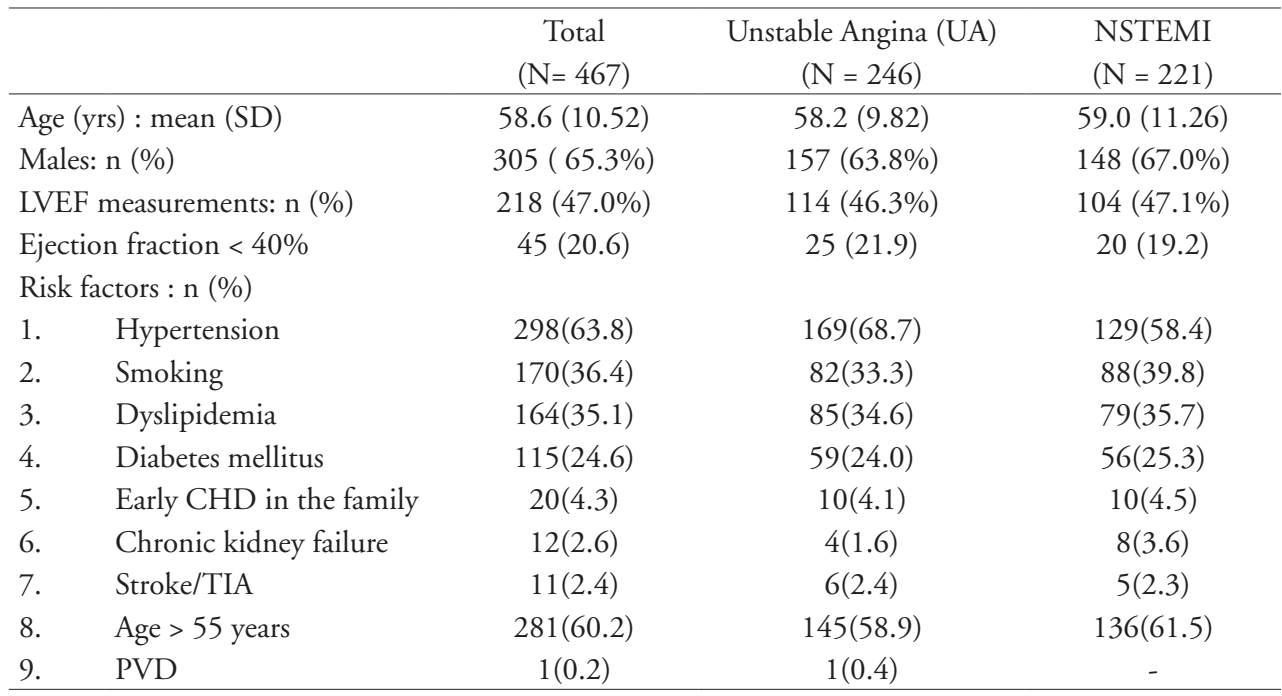

CHD: coronary heart disease, TIA: transient ischemic attack, PVD: peripheral vascular disease

Table 2. Onset of ACS

\begin{tabular}{lccc}
\hline & $\begin{array}{c}\text { Total } \\
(\mathrm{N}=467)\end{array}$ & $\begin{array}{c}\text { Unstable Angina }(\mathrm{UA}) \\
(\mathrm{N}=246)\end{array}$ & $\begin{array}{c}\text { NSTEMI } \\
(\mathrm{N}=221)\end{array}$ \\
\hline NSTEACS onset (\%) & & & \\
$<12 \mathrm{hrs}$ & $61.0 \%$ & $61.8 \%$ & $60.2 \%$ \\
$12-<24 \mathrm{hrs}$ & $18.2 \%$ & $14.2 \%$ & $22.6 \%$ \\
$24-72 \mathrm{hrs}$ & $18.2 \%$ & $21.5 \%$ & $14.5 \%$ \\
$>72 \mathrm{hrs}$ & $1.5 \%$ & $1.6 \%$ & $1.4 \%$ \\
not available & $1.1 \%$ & $0.8 \%$ & $1.4 \%$ \\
\hline
\end{tabular}


were given to $89.2 \%$ of patients. Patients treated with aspirin alone or clopidogrel alone were $2.2 \%$ and $8.6 \%$ respectively. Medical treatment group treated with clopidogrel received a loading dose of $300 \mathrm{mg}$ in $373 / 467(80 \%)$ and $600 \mathrm{mg}$ in only $4 / 467$ patients (0.9\%). An aspirin loading dose of $160 \mathrm{mg}$ and 320 mg were given to $45 \%$ and $28 \%$ of patients who were treated with aspirin respectively.

Table 4 shows anticoagulant treatment during hospitalization. There were 51 patients who have their anticoagulant treatment not recorded. Most of the patients (46.9\%) received enoxaparin for $4-5$ days. Unfractionated heparin and fondaparinux was given for 3 and $4-5$ days respectively.
GRACE score could be evaluated in 454 patients. Low to moderate GRACE score were detected in about 99\% of patients (see Table 6). GRACE risk score was higher among the patients with NSTEMI than unstable angina.

\section{Discussion}

Medically Managed Registry is a multicentre registry performed in 18 hospitals in Indonesia during December 2009 to January 2011 where 10 of these hospitals have the ability to perform coronary intervention. The mean age of patients in this registry

Table 5. Anticoagulant therapy during hospitalization

\begin{tabular}{lccr} 
& Total & Unstable Angina & \multicolumn{1}{c}{ NSTEMI } \\
& $(\mathrm{N}=416)$ & $(\mathrm{N}=217)$ & $39(19.6 \%)$ \\
\hline UFH & $80(17.1 \%)$ & $41(18.9 \%)$ & $112(56.3 \%)$ \\
Enoxaparin & $235(46.9 \%)$ & $123(56.7 \%)$ & $48(24.1 \%)$ \\
Fondaparinux & $101(21.4 \%)$ & $53(24.4 \%)$ & \\
\hline
\end{tabular}

UFH: unfractionated heparin

Table 5. Oral medications (other than antiplatelets) given during hospitalization

\begin{tabular}{llccc}
\hline & & $\begin{array}{c}\text { Total } \\
(\mathrm{N}=467)\end{array}$ & $\begin{array}{c}\text { Unstable Angina (UA) } \\
(\mathrm{N}=246)\end{array}$ & $\begin{array}{c}\text { NSTEMI } \\
(\mathrm{N}=221)\end{array}$ \\
\hline 1. & Oral nitrates & $386(82.7)$ & $203(82.5)$ & $183(82.8)$ \\
2. & Beta blockers & $284(60.8)$ & $144(58.5)$ & $140(63.3)$ \\
3. & ACE inhibitors & $229(49.0)$ & $115(46.7)$ & $114(51.6)$ \\
4. & Diuretics & $135(28.9)$ & $60(24.4)$ & $75(33.9)$ \\
5. & Angiotensin receptor blockers & $95(20.3)$ & $50(20.3)$ & $45(20.4)$ \\
6. & Calcium channel blockers & $93(19.9)$ & $46(18.7)$ & $47(21.3)$ \\
7. & Statins & $61(13.1)$ & $27(11.0)$ & $34(15.4)$ \\
\hline
\end{tabular}

Table 6. GRACE Risk Score

\begin{tabular}{lccc}
\hline & $\begin{array}{c}\text { Total } \\
(\mathrm{N}=454)\end{array}$ & $\begin{array}{c}\text { Unstable Angina }(\mathrm{UA}) \\
(\mathrm{N}=236)\end{array}$ & $\begin{array}{c}\text { NSTEMI } \\
(\mathrm{N}=218)\end{array}$ \\
\hline Low $(<100)$ & $290(63.9 \%)$ & $165(67.1 \%)$ & $125(56.6 \%)$ \\
Medium $(100-149)$ & $160(35.2 \%)$ & $70(28.5 \%)$ & $90(40.7 \%)$ \\
High $(>150)$ & $4(0.9 \%)$ & $1(0.4 \%)$ & $3(1.4 \%)$ \\
\hline
\end{tabular}

More patients were treated with oral nitrates than with beta-blockers or ACE-inhibitors (see Table 5). Statins were given to less than $15 \%$ of patients. Diuretics (furosemide) were given to those with heart failure. were 58.6 years and this is almost similar with the age reported in South East Asia and Japan acute myocardial infarction study ( 57 years) but somehow younger than study from China and Hong Kong (63 years). ${ }^{2}$ Patients recruited in this registry were also younger than that 
reported in the GRACE model. ${ }^{3}$

Left ventricular ejection fraction is an independent predictor of mortality and other major adverse cardiac events in UA/NSTEMI. Among 47\% of patients who have their LVEF measured during hospitalization, 20.6\% have LVEF less than $40 \%$. This result might have some clinical implications. Invasive strategy is generally preferred for patients with low LVEF $(\leq$ 40\%). ${ }^{4,5,17}$ Angiotensin converting enzyme (ACE) inhibitors and angiotensin receptor blockers (ARBs) are well established in secondary prevention ${ }^{6,7}$ and are especially indicated for patients with reduced LV function. Beta-blockers are also recommended in all patients with reduced LV systolic function.

In this study hypertension was detected in $63.8 \%$ of patients which was the highest amongst all risk factors, followed by smoking, dyslipidemia, and diabetes. In the Global Registry of Acute Coronary Events (GRACE), prior or current smoking and hypertension were present as risk factors in more than half of the patients. Approximately $45 \%$ of patients had a diagnosis of hyperlipidemia and less than $25 \%$ had diabetes mellitus. ${ }^{3}$ The INTERHEART study suggested the risk of myocardial infarction (MI) attributable to hypertension and other risk factors like smoking, lipids, diabetes, abdominal obesity, and the combined psychosocial index is likely to be similar across most region of the world, including Asia. ${ }^{2}$ The INTERHEART study recorded $15 \%$ of MI was attributed to hypertension. The burden of MI associated to hypertension in South-east Asia and Japan was the highest among all regions, much higher than that in South Asia and China. The reason for this is identifiable by the high prevalence of hypertension in Japan and some region in South-East Asia such as Indonesia. Therefore, it has been suggested that the overall approach to the prevention of MI attributed to hypertension could be similar worldwide, but with varying emphasis in geographic region on the basis of the prevalence of hypertension. National hypertension prevalence for person aged over 15 years was $29.8 \%$ and only $24 \%$ of them were aware of the diagnosis. ${ }^{8}$

Around $60 \%$ of the patients in this registry reached emergency department before 12 hours from the onset of ACS. Focus groups conducted for the REACT research program ${ }^{9,10}$ revealed that patients commonly hold a preexisting expectation that a heart attack would present dramatically with severe, crushing chest pain, such that there would be no doubt that one was occurring. Other published reasons for any delays were that patients thought their symptoms were selflimiting and would go away or were not serious. ${ }^{11,12}$ As a comparison, the Thai Acute Coronary Syndrome Registry (TACSR) observed the median time from the onset of the episode of chest pain to admission was 6.0 hours. ${ }^{13}$ The OPERA registry in France observed the median time between symptom onset and arrival at hospital was 6 hours and was shorter in patients with STEMI vs. those with NSTEMI ( 4 vs. 7 hours, $P<0.0001) .{ }^{14}$

Variables such as age, heart rate, systolic blood pressure, serum creatinine level, Killip class at admission, presence of ST-depression, and elevated cardiac biomarkers as well as cardiac arrest are included in the calculation of GRACE MODEL. ${ }^{1}$ In this registry, low to moderate GRACE risk score were able to stratified in about $99 \%$ of patients in this registry. GRACE risk score was found to be higher among patients with NSTEMI than those with unstable angina. Patients with high GRACE score in this study might have undergone PCI considering that 10 out 18 participating hospitals have the ability to perform coronary intervention. During hospitalization, 57 patients (12.2\%) underwent PCI 3 - 4 days after admission.

The in-hospital mortality rate in low and intermediate risk categories according to the GRACE risk score is less than $1 \%$ and $1-3 \%$ respectively. ${ }^{1}$ Hospital mortality in this registry was $3.2 \%$, which was higher among patients who underwent PCI $(5.3 \%)$ compared to those in the medical treatment group. This showed that patients who underwent PCI during hospitalization have a higher risk than those who did not. As a comparison, in-hospital mortality of patients admitted with non-ST-elevation ACS from 2002 to 2005 was as high as $9.5 \%$ in the Thai Acute Coronary Syndrome Registry (TACSR) ${ }^{13}$. Inhospital mortality in this registry was $0.4 \%$ and $6.3 \%$ in patients admitted for unstable angina and NSTEMI respectively, which was lower than that observed in the Acute Coronary Syndrome (ACS) Registry in Malaysia (3\% for unstable angina and 7\% for NSTEMI).

This registry showed that most of the patients were treated with antiplatelets according to current guidelines. ${ }^{4,5,17}$ Almost $90 \%$ of the patients received a combination of aspirin and clopidogrel. A loading dose of $300 \mathrm{mg}$ clopidogrel was given to $94 \%$ of medical treatment patients and a loading dose of $160 \mathrm{mg}$ to 320 mg aspirin was also given to $91 \%$ of these patients.

In the CURE trial (Clopidogrel in Unstable 
Angina to Prevent Recurrent Events), a clopidogrel hydrogen sulfate $300 \mathrm{mg}$ loading dose followed by 75 mg daily maintenance for $9-12$ months in addition to aspirin could reduce the incidence of cardiovascular death and non-fatal MI or stroke by $20 \%$ compared with aspirin alone. ${ }^{16}$ The study suggests that a delay of even one day in initiating clopidogrel after the onset of symptoms of ACS exposes a patient to a significant risk of cardiovascular death, myocardial infarction, stroke and severe ischemia. In this study some patients were treated with aspirin or clopidogrel alone.

Current data from this registry showed that clopidogrel data was not available to all patients and some doctors tend to avoid aspirin therapy for patients with a history of aspirin intolerability when these patients were hospitalized with diagnoses of ACS. All patients were receiving injectable anticoagulants as recommended by guidelines. Almost half of the patients were treated with enoxaparin which was twice higher than those treated with fondaparinux. Only $17.1 \%$ of patients were treated with unfractionated heparin.

More than $80 \%$ of patients received oral nitrates. The use of nitrates in unstable angina is largely based on pathophysiological considerations and clinical experience. There are no randomized placebocontrolled trials to confirm efficacy of this class of drugs in reducing risk of major adverse cardiac events. Guidelines recommend the use of medications that have been established in reducing risk of major adverse cardiac events such as ACE-inhibitors, beta blockers, and statins. ACE inhibitors or ARBs are well established in secondary prevention and are especially indicated in patients with reduced LV function. Oral beta-blockers are indicated for ACS patients with concomitant tachycardia, hypertension, or LV dysfunction. Statin therapy with target LDL-C levels $<70 \mathrm{mg} / \mathrm{dL}$ initiated early after admission is recommended.

Data from this registry showed that patients with ACS in this study were under treated with ACEinhibitors (or ARBs), beta blockers, and especially statins. Efforts need to be done to implement these drugs to more patients in order to reduce cardiac events.

\section{References}

1. Fox KA, Dabbous OH, Goldberg RJ, Pieper KS, Eagle KA, Van de Werf F, Avezum A, Goodman SG, Flather MD, Anderson FA Jr., Granger CB. Prediction of risk of death and myocardial infarction in the six months after presentation with acute coronary syndrome: prospective multinational observational study (GRACE). BMJ 2006; 333: 1091.

2. Yusuf S, Hawken S, Ôunpuu S, Dans T, Avezum A, Lanas F, McQueen M, Budaj A, Pais P, Varigos J, Lisheng L, on behalf of the INTERHEART Study Investigators. Effect of potentially modifiable risk factors associated with myocardial infarction in 52 countries (the INTERHEART study): case-control study. Lancet 2004; 364: 937 - 52

3. Eagle KA, Lim MJ,. Dabbous OH, Pieper KS, Goldberg RJ, Van de Werf F, Goodman SG, et al for the GRACE Investigators. A validated prediction model for all forms of acute coronary syndrome: estimating the risk of 6-month postdischarge death in an international registry. JAMA 2004; 291: 2727 - 2733

4. Wright RS, Anderson JL, Adams CD, Bridges CR, Casey DE Jr, Ettinger SM, Fesmire FM, Ganiats TG, Jneid H, Lincoff AM, Peterson ED, Philippides GJ, Theroux P, Wenger NK, Zidar JP. 2011 ACCF/AHA focused update of the guidelines for the management of patients with unstable angina/non-ST-elevation myocardial infarction (updating the 2007 guideline): a report of the American College of Cardiology Foundation/American Heart Association Task Force on Practice Guidelines. J Am Coll Cardiol 2011; 57: 1920 - 59

5. Hamm CW, Bassand JP, Agewall S, Bax J, Boersma E, Bueno H, Caso P, Dudek D, Stephan Gielen, Huber K, Ohman M, Petrie MC, Sonntag F, Uva MS, Storey RF, Wijns W, Zahger D. ESC Guidelines for the management of acute coronary syndromes in patients presenting without persistent ST-segment elevation. Eur Heart J doi:10.1093/eurheartj/ehr236

6. Dagenais GR, Pogue J, Fox K, Simoons ML, Yusuf S. Angiotensin converting enzyme inhibitors in stable vascular disease without left ventricular systolic dysfunction or heart failure: a combined analysis of three trials. Lancet 2006; 368: 581 588

7. Danchin N, Cucherat M, Thuillez C, Durand E, Kadri Z, Steg PG. Angiotensinconverting enzyme inhibitors in patients with coronary artery disease and absence of heart failure or left ventricular systolic dysfunction: an overview of long-term randomized controlled trials. Arch Intern Med 2006; 166: 787 $-796$

8. The National Institute of Health Research and Development, Ministry of Health, Republic of Indonesia. Report on Result of National Basic Health Research (RISKESDAS) 2007.

9. Luepker RV, Raczynski JM, Osganian S, et al. Effect of a community intervention on patient delay and emergency medical service use in acute coronary heart disease: the Rapid Early Action for Coronary Treatment (REACT) trial. JAMA 2000; 284: $60-7$

10. Feldman HA, Proschan MA, Murray DM, et al. Statistical design of REACT (Rapid Early Action for Coronary Treatment), 
a multisite community trial with continual data collection. Control Clin Trials 1998; 19: 391 - 403

11. Leslie WS, Urie A, Hooper J, Morrison CE. Delay in calling for help during myocardial infarction: reasons for the delay and subsequent pattern of accessing care. Heart 2000; 84: 137 $-41$

12. Rucker D, Brennan T, Burstin H. Delay in seeking emergency care. Acad Emerg Med 2001; 8: 163 - 9

13. Kiatchoosakun S, Wongvipaporn C, Buakhamsri A, Sanguanwong S, Moleerergpoom W, Sarakarn P, Silaruks S, Tatsanavivat P. Predictors of In-Hospital Mortality in Non-ST Elevation Acute Coronary Syndrome in Thai Acute Coronary Syndrome Registry (TACSR). J Med Assoc Thai 2007; 90 (Suppl 1): 41-50.

14. Montalescot G, Dallongeville J, Van Belle E, Rouanet S, Baulac C, Degrandsart A, Vicaut E for the OPERA Investigators. STEMI and NSTEMI: Are They So Different? 1 Year Outcomes in Acute Myocardial Infarction as Defined by the ESC/ACC Definition (the OPERA Registry). Eur Heart J 2007; 28: 1409
$-1417$.

15. Chin SP, Jeyaindran S, Azhari R, Wan Azman WA, Omar I, Robaayah Z, Sim KH. Acute Coronary Syndrome (ACS) Registry - Leading the Charge for National Cardiovascular Disease (NCVD) Database. Med J Malaysia 2008; 63(Suppl C): 29 36

16. Yusuf S, Zhao F, Mehta SR, Chrolavicius S, Tognoni G, Fox KK. Effects of clopidogrel in addition to aspirin in patients with acute coronary syndromes without ST-segment elevation. N Engl J Med 2001; 345: 494 - 502

17. Anderson JL, Adams CD, Antman EM, Bridges CR, Califf RM, Casey DE, Chavey WE, Fesmire FM, Hochman JS, Levin TN. ACC/AHA 2007 Guidelines for the Management of Patients With Unstable Angina/Non-ST-Elevation Myocardial Infarction. A Report of the ACC/AHA Task Force on Practice Guidelines (Writing Committee to Revise the 2002 Guidelines for the Management of Patients with Unstable Angina/NonST-Elevation Myocardial Infarction). Circulation 2007; 116: e148-e304. 


\section{Appendix}

Full list of Medically Managed Registry Investigators:

1. Dr. Erwinanto, SpJP, Division of Cardiology \& Vascular Medicine, Hasan Sadikin Hospital, Bandung (Principal Investigator)

2. Dr. Richard Indragunawan, SpJP, Borromeus Hospital, Bandung

3. Dr. Angke Widya, SpJP, Borromeus Hospital, Bandung

4. Dr. Kiki Abdurachim Nazir, SpJP, Santosa International Hospital, Bandung

5. Dr. Mira Rahmawati, SpJP, Cibabat Hospital, Cimahi

6. Dr. Dolly Kaunang, SpJP, Husada Hospital, Jakarta

7. Dr. Eddy Sunaryuniarto, SpJP, Fatmawati Hospital, Jakarta

8. Dr. Sri Diniharini, SpJP, Puri Cinere Hospital, Depok

9. Dr. Erwin S. Setiawan, SpJP, Mitra Keluarga Hospital, Bekasi Timur

10. Dr. Cholid Tri Tjahjono, SpJP, Saiful Anwar Hospital, Malang

11. Dr. Niniek Purwaningtyas, SpJP, Dr. Moewardi Hospital, Surakarta

12. Dr. Nahar Taufik, SpJP, Division of Cardiology \& Vascular Medicine, Sardjito Hospital, Yogyakarta

13. Dr. Dyana Sarvasti, SpJP, Husada Utama Hospital, Surabaya

14. Dr. Prihati Pujowaskito, SpJP, Dustira Hospital, Cimahi

15. Dr. IGN Putra Gunadhi, SpJP(K), Division of Cardiology \& Vascular Medicine, Sanglah Hospital, Denpasar

16. Prof. Dr. Sutomo Kasiman, SpPD-KKV, Gleni International Hospital, Medan

17. Dr. Irwan, SpJP, Santa Maria Hospital, Pekanbaru

18. Dr. Roy Christian, SpJP, Sari Asih Hospital, Tangerang 